\section{$2 \mathrm{O} 1400$}

ADP inhibitionのかかりにくい変異体 F1-ATPase の酵素学的性質と回転 (2)

○宗行 英朗 1 、鈴木 徹也 1 、井合 健太郎 ${ }^{1}$ 、野地 博行 2,3 、西

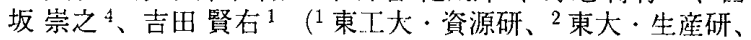
3 さきがけ $21 、 4$ 通信総合研究所・生体物性 $\mathrm{G}$ )

F1-ATPase はATPを加水分解している最中にADPを触媒部位に固 く結合した不活性化状態に扝ちいる。この不活性化は単なる生成物阻 害ではなく、この阻害型の存在がFl-ATPaseの種々の解析を相難に してきた，昨年度，我々は回転実験用の変異体のßサブユニットに更 にT165S, G181A，Y341Wの変異を導入してこのADP inhibitionを 大幅に軽減することに成功した（GT 変異体と呼ぶ），本年は昨年に 引き続き，この $\mathrm{GT}$ 変異体の生化学的性質と回転について報告する. GT 変異体は $4 \mathrm{mM} \mathrm{ATP}$ 存在下で約 $240 \mathrm{~s}-1$ の反応速度を示した。 反 応の初期にラグが見られるため, 正確なATP 湄度依存性の測定は困 難であるが，ほぼ単純な Michaelis-Mfent.n 型のパターンを示し，その Kmは30-50"Mの間と見積もられた. ADP inhibitionをほとんど受 けないが，及Y Y $341 W$ の蛍光強度から見積もった触媒部位のADPに 対する親和性は他の変異体とほとんど変わらなかった。また，ADP 共存下でのATPase 活性は比較的素直な競争阻害の形をとり，その $\mathrm{Ki}$ は及 $3341 W の$ 蛍光强度から見積もった 3 番目のADPの結合の Kd と同じオーダーであった。微小ビーズを結合したG厂変異体の回転 速度は変異を導入していないものに比べて若干遅い傾问があり, 低濃 度 ATPでは, ATPの konが低くなるように見える。また，飽和 ATP 濃度でも短いステップが観察される。昨年に引き続き, ATP, ADP, リン酸の濃度を変化させて，ATPの加水分解の自由工ネルギーを制 御した条件下での回転観察を行っているが，リン酸 $100 \mathrm{mM}, \mathrm{ADP}$ がATPの 100 倍以上の濃度で共存した条件下でも回転が観察されて いる. 現在，単一ステッップを明暸に観察できるように努力している。

E. Muneyuki. T. Suzuki, K. Tai. H. Noji T Nishizaka and M. Yoshida : A mutant F1-ATPase resistant to ADP inbibition (2)

\section{0}

\section{F1-ATPase からのATP の解離}

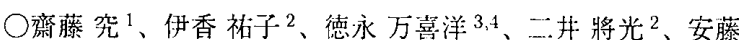
敏夫 ${ }^{1}$ (1 金沢大学院・自然科学、 2 限大・産業科学研究所、3 遗伝研、 ${ }^{4}$ 理研・免疫七)

$\mathrm{F}_{0} \mathrm{~F}_{1}$-ATP 合成酥素は水素イオン濃度勾配のエネルギーを利用して ATP を合成している。ATP 合成を触媒する $F_{1}$-ATPase 部分はATP を加水分解する際に中心の $\gamma$ サブユニットを回転させている。この回 転運動とATPの加水行解の関係については、近年、 $\gamma$ サブユニット に結合させたマーカーの回転を頙微鏡下で観察することにより解析が 淮んでいる。令成のメカニズムに関して依然不明な点は多いが、分解 反応と同様に $\gamma$ サブユニットの回転がATP 合成に密接に関係してい ることが予想されている。

$\mathrm{F}_{1}$-ATPase からのATPの解離について解析することは合成反応のメ カニズムに近づく手がかりとなる。今回、F $F_{1}$-ATPascに過剩量のADP を加えることによるATPの放出を測定したので報告する。精製した F 1 -ATPaseにあらかじめnMオーダーのATPを結合させて扩く。そ こに数 10 から数 $100 \mu \mathrm{M}$ のADP を加えることにより定常的なATP の放出を計測することができた。ATPの解離速度はADP濃度に依 存して大きくなった。また、溶液中のリン酸濃度にも依存し、WTの $F_{1}$-ATPase ではリン酸濃度が高いほどATPの解離速度が低くなる結 果となった。ATPaseの低くなるミュータント３S174Fや、BS174F/ ß G149Aに持けるATP放出速度についても計測を行ったので、これ らの結果をふまえATP 合成について考察したい。

K. Saito. Y. Iko, M. Tokunaga, M. Futai and T. Ando: ATP release? from F1-ATPase

\section{5}

Mg-free ADP が一個結合した F1の構造と触媒機構 との関連

○白木原康雄 ${ }^{1}$ 、鈴木 悛治 ${ }^{2}$ 、白鳥 綾 1 、白木原 千佳子 ${ }^{1}$ 、中

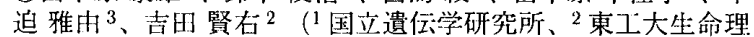
学、 ${ }^{3}$ 慶応・理工.)

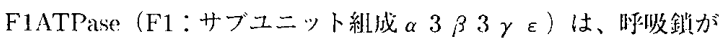
形成する脱を淂てた水絜イオンの濃度空をATPに変換するATP 合

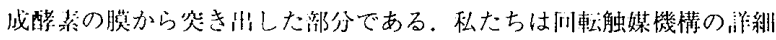

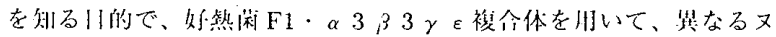

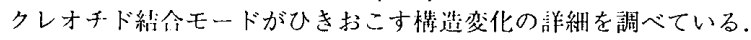

今间、M-frec ADPが1䛧だけßサブユニットに結介したF1の

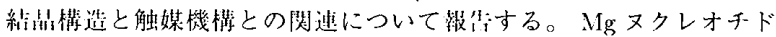

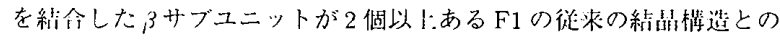
比較により、ヌクレオチド絬令の変化に伴う $\alpha 3 \beta 3$ コア部分の棈措

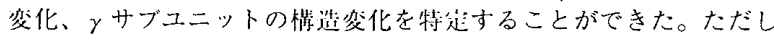
Mg-frecの制約の十分な考虑が必要であった。

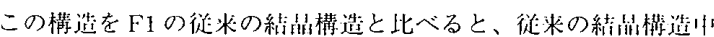

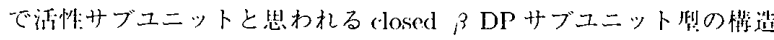

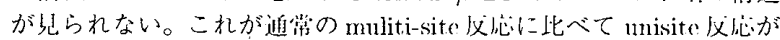

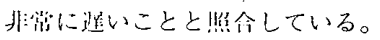

また $\gamma$ サブユニットを2個ヌクレオチドを䋨命したßサブユニッ

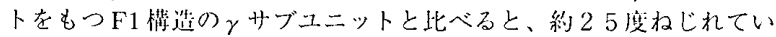
た。こ机は1分了汁測から得られた、敞物ADP.Piの放虬に俳う 30

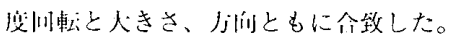

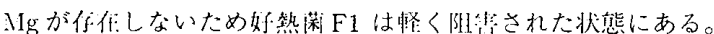

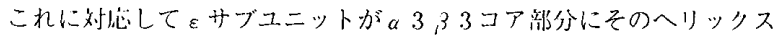

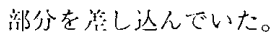

Y. Shirakihara, T. Suzıki, A. Shiratori, C. Shirakihara, M. Nakasoko \& M.Yoshida : Structure of F1-ATPase with nucleotide bound to a single catalytic site and its Implications

\section{5}

低ATP濃度における F 1 -ATPase の回転とヌクレオ チド結合数

O榊 直由 ${ }^{2}$ 、下理恵子 1 、伊藤博康 ${ }^{2}$ 、足立健吾 ${ }^{1}$ 、宗行 英 朗 3 、吉田賢右 ${ }^{3}$ 、末下 - . 彦1 (1 岡崎・統合バイオ、2 浜松 ホトニクス・筑波研究所、3 東工大・資源化学)

$F_{1}$-ATPase（以下、F，と略寸）は、ATPの加水分解に上って回転 する分子モーターである。 の1つにだけ結合した状態では回転せず、2つ以、上のATPが結合し た状態を経なけ机ば回転しないと考えられている。しかし、2つめの ATP 結合が $\mathrm{F}$ の回転に寄与していると考える bi-site 説と、2つめた けでなく3つめのATPが結合してはじめて回転すると考える tri-site 説の $2 つ の$ 説があり、どちらが正しいかは決着がついていない。

これを解決するために、われわれはまず低 ATP 濃度に执けるF の回転速度の ATP 濃度依存性を测定することにした。Ni-NTA コー トしたガラス表而にHis-tag 付きのF，を固定し、F $F_{1}$ のサブユニッ トにビオチンを介してストレプトアビジンビーズをつけ、低ATP濃 度 (20～６00 $11 \mathrm{~N}$ ATP）での回転を観察した。トリプトファン消光加 ら見積もったヌクレオチド結合数によれば、この範囲のATP 濃度は bi-site モードの領域であると考えられる。100回転以上のほほ連続的 な回転が 20 nM ATP でも観察された。これはbi-sitc 説を支持するも のである。なぜなら、20 nM ATPはF,の3つめのATP に対する解 朔定数よりもはるかに低く、3つめのATPが $F_{1}$ の連続的な回転に寄 与しているとは考えにくいからである。

現在、F、へのヌクレオチド結合数の直接測定も試及ており、回転 観察の結果とあわせることで、2つの説のうちどちらが正しいかの決 着をつけたいと考えている。
N.Sakaki, R.Shimo, H.Itoh, K.Adachi. E.Muneyuki, M.Yoshida and K.Kinosita.Jr : Rotation and site oce unancy of $F_{1}$-ATPase at low ATP concentrations 